\title{
PRODUCTION OF XYLANASES BY STREPTOMYCES SPECIES AND THEIR BLEACHING EFFECT ON RICE STRAW PULP
}

\author{
H. M. RIFAAT ${ }^{1 *}-$ Z. A. NAGIEB ${ }^{2}-$ Y. M. AHMED ${ }^{3}$ \\ *e-mail: halamohamed6@hotmail.com. \\ ${ }^{I}$ Microbial Chemistry Dept., National Research Centre, Dokki, Cairo, Egypt. \\ ${ }^{2}$ Paper and Cellulose Dept., National Research Centre, Dokki, Cairo, Egypt. \\ ${ }^{3}$ Microbial Biotechnology Dept., National Research Centre, Dokki, Cairo, Egypt. \\ *Corresponding author
}

(Received $12^{\text {th }}$ May 2005, accepted $4^{\text {th }}$ August 2005)

\begin{abstract}
The number of potential applications of microbial xylanases in the pulp and paper industry is gradually increasing and several are approaching commercial use. This industry needs a xylanase, which is free of cellulase. Twenty isolated Streptomycetes strains from Egyptian soils, which produce cellulase free-xylanase and are easily grown using a low-cost agriculture waste substrate, were investigated. The two most active strains have been identified as Streptomyces albus and Streptomyces chromofuscus. Their maximum xylanase activity was $13.25,19.31$ and $32.53,43.01$ on untreated rice straw pulp and pulp treated with $\mathrm{TiO}_{2}$ in both Streptomyces species respectively. The enzyme activity increased when both isolates were grown on yeast extract. Optimum production of xylanase was recorded after five days of fermentation. Xylanase produced with Streptomyces chromofuscus showed higher bleaching activity than that from Streptomyces albus. The enzyme enhanced the liberation of reducing sugars, which improved pulp bleachability.
\end{abstract}

Key words: Streptomyces sp., cellulase-free xylanases, rice straw pulp, biobleaching.

\section{Introduction}

Xylan is widely distributed in plant cell walls and forms a main part of the hemicellulose fraction [29]. In some higher plants and agricultural wastes, xylan constitutes from 20-40\% of the dry weight [5 and 19]. Xylan together with hemicellulose forms the second most abundant renewable polysaccharide in the biosphere. It has been estimated that 500 million tons of such materials could be annually available from the residues of major crops [5]. Effective extraction by enzymatic and microbiological processes of these materials is of great interest. Hemicellulase and endoxylanase enzymes have been extensively studied, since they hydrolyse polysaccharides in the pulp of woods [8]. An attractive application of this hydrolysis process is the removal of xylan from wood pulp for manufacturing of dissolved pulp.

Recently, the interest in cellulase-free xylanases has focused on pulping and bleaching processes, in which chlorine $(\mathrm{Cl} 2)$ and hypochlorine $(\mathrm{ClO} 2)$ for biobleaching can be reduced [25, 13 and 14]. Naturally occurring microbial strains capable of secreting xylanases free of cellulase activity would be attractive for such applications. The most important enzyme needed for enhancing the bleaching of pulp is endo-Bxylanase [10, 18 and 26]. Xylanases enhance the cleaving of reprecipatated xylan formed on the outer surfaces of the cellulose fibers after pulping [11]. This causes increased permeability of the pulp fibers to the bleaching chemicals and allows the passage of larger fragments of residual lignin out of the pulp. 
Xylanases have been isolated from a wide range of microorganisms including fungi, actinomycetes and eubacteria. Actinomycetes enzymes, which are thermostable, are of particular interest. Most actinomycete strains secreting high activity xylanases free of substantial cellulase activity are thermotolerant: Streptomyces sp. [12], Saccharomonospora [20] and Streptomyces roseiscleroticus [6]. Treatment with xylanases can improve the chemical extraction of lignin from pulp. This would lead to a significant reduction in the amount of chemicals required for bleaching and, hence, in the levels of toxic chlorine compounds released into the environment.

The present paper deals with the production of xylanase enzymes from various xylan assimilating streptomycetes strains as potent producers of xylanase. In addition, the nutritional requirement and optimum fermentation condition for maximum yield of xylanase have been studied. The effect of the produced xylanase on the bleachability of pulp was also investigated.

\section{Material and methods}

\section{Strain isolation}

The cultures were isolated from a soil sample containing decomposed rice straw pulp detritus on a basal medium containing (g/l: 2.0 KNO3, 1.0 K2HPO4, 0.5 MgSO4, 3.0 $\mathrm{CaCO} 3,0.01 \mathrm{FeSO} 4$ and 20.0 agar). Plates were incubated at $28 \mathrm{oC}$ for seven days and single colonies were evaluated for growth. Streptomycetes colonies were picked followed by purification and preliminary evaluation of the isolates in shake flasks. Two of the strains, which showed high activity of xylanase production, were taken for detailed investigation.

\section{Characterisation of the two selected isolates}

Characterisation of the active isolates of streptomycetes was done through polyphasic characterisation. Morphological, physiological, chemotaxonomical and molecular identification were carried out according to various methods [22, 30, 9 and $15]$.

\section{Culture media and conditions}

The same previous basal medium was used. The $\mathrm{pH}$ was adjusted to 7.0-7.2 and the pulp substrate $(2 \% \mathrm{w} / \mathrm{v})$ was added prior to sterilisation by autoclave at $121 \mathrm{oC}$ for 15 min. Shake flask cultivations were carried out with $50 \mathrm{ml}$ of medium in $250 \mathrm{ml}$ flasks at $28 \mathrm{oC}$ and shaking at $200 \mathrm{rpm} / \mathrm{min}$. Cultivation was done for 5 days after inoculation of $5 \mathrm{ml}$ of a 5 -day culture prepared on starch nitrate medium.

\section{Xylanase assay}

The activity of xylanase was measured by determining the release of reducing sugars from soluble xylan. The reaction mixture consisted of $5 \mathrm{ml}$ of xylan solution $(3 \%$ as anhydroxylose), $4 \mathrm{ml}$ of $0.1 \mathrm{M}$ phosphate buffer ( $\mathrm{pH} 6.5$ ) and $1 \mathrm{ml}$ of enzyme solution. The reaction was run at $40 \mathrm{oC}$ for $30 \mathrm{~min}$. Increase of reducing sugars in the mixture was determined as xylose by the method of Somogyi [17]. One unit of xylanase is defined as the amount of enzyme, which is capable of liberating $1 \mathrm{MM}$ equivalent of xylose in one minute. Cellulase activity was also determined using the same procedure in addition to $5 \mathrm{mg} / \mathrm{ml}$ cellulose. 


\section{Pulping}

Rice straw was cut into 3-4 $\mathrm{cm}$ then extracted by a mixture of methanol and benzene $(1: 1)$ for 6 hour to remove waxes and resins. The residual material was air dried. Soft wood soda pulps were prepared by cooking these dried materials under the following conditions: total alkali $12 \%$ and cooking temperature $160 \mathrm{oC}$ for 1 hour.

\section{Treatment of the pulp with $\mathrm{TiO}_{2}$}

Pulp was impregnated in water, $\mathrm{TiO} 2$ was added as fine powder and the bulk was beaten up to So SoR in a Jorko mill beaker at 150 r.p.m.

\section{Pulp properties}

Kappa number, degree of brightness and degree of polymerisation were carried out according to the method of Casey [3]. Kappa number is used to describe the degree of delignification obtained in the chemical and/or enzymatic process. Degree of brightness $(\%)$, which means the whiteness of the tested paper, was measured by using a Hunter Lab colour/ Difference Meter D25-2 at wavelength $457 \mathrm{~nm}$. Degree of polymarisation (DP) is a function of average length of the cellulose chains and of fiber length. It is one of the significant factors of cellulose sample strength.

\section{Scanning electron microscope}

Pulp samples were coated by thin layer of gold and investigated by Jeol JXA-840 $\AA$ Electron Microscope.

\section{Results and discussion}

\section{Strain characterisation}

Twenty Streptomyces isolates from Egyptian soils were screened for their xylanolytic activity. The most two active isolates have been taxonomically characterised. Based on the polyphasic characterisation (morphological, physiological, chemotaxonomical and $16 \mathrm{~S}$ rDNA sequences), the selected two isolates could be identified as Sterptomyces albus and Streptomyces chromofuscus.

\section{Xylanase production by Streptomyces sp.}

Xylanase production using Sterptomyces albus and Streptomyces chromofuscus was improved with untreated and treated rice straw pulp as substrate. As shown in Table 1, xylanase was produced on treated pulp with a maximum activity of $43.01 \mathrm{u} / \mathrm{ml}$. Streptomyces chromofuscus exhibited a higher xylanase activity using either untreated or treated pulp as substrate rather than Sterptomyces albus (Table 1).

Table 1. Xylanase production by Streptomyces species growing on pulp at $2 \% \mathrm{w} / \mathrm{v}$ after 5 days

\begin{tabular}{|l|c|c|}
\hline \multirow{2}{*}{ Substrate } & \multicolumn{2}{|c|}{ Maximum xylanase activity (u/ml) } \\
\cline { 2 - 3 } & Streptomyces albus & Streptomyces chromofuscus \\
\hline Untreated pulp & 13.25 & 19.31 \\
\hline Treated pulp withTiO & 32.53 & 43.01 \\
\hline
\end{tabular}

Cellulase activity was not detected in the culture supernatants of both cases. The activates of 19.31 or $13.25 \mathrm{u} / \mathrm{ml}$ on untreated pulp were comparable or slightly lower than those reported for most other mesophilic actinomycetes that produce cellulase-free 
xylanase. Antonopoulos et al. [1] reported $12 \mathrm{u} / \mathrm{ml}$ of xylanase in a 5 day culture of Sterptomyces albus. Similar low levels of cellulase-free xylanase produced from treated crude agricultural waste have been reported. Growth of xylanase was inducible by treated rice straw pulp in both Streptomyces species.

\section{Effect of cultural conditions on xylanase production}

\section{Effect of various carbon sources on xylanase production}

The activity response of Sterptomyces albus and Streptomyces chromofuscus grown on different carbohydrate sources is shown in Table 2. The highest xylanase production was obtained with 20.0 gram xylan as sole carbon sources for both Streptomyces strains. Glucose, xylose, maltose, sucrose, dextrin and cellulose could simulate enzyme activity, although they support the growth of the Streptomyces species. These results obtained are in agreement with those reported by Techapun et al. [23 and 24].

Table 2. Effect of various carbon sources on xylanase production from Streptomyces species after 5 days in case of untreated sample

\begin{tabular}{|l|c|c|}
\hline \multicolumn{1}{|c|}{ Carbon sources 2\% } & \multicolumn{2}{|c|}{ Maximum enzyme activity u/ml } \\
\cline { 2 - 3 } & Streptomyces albus & Streptomyces chromofuscus \\
\hline Xylan & 49.92 & 60.49 \\
\hline Cellulose & 15.45 & 16.45 \\
\hline Dextrin & 16.31 & 18.71 \\
\hline Sucrose & 12.22 & 15.52 \\
\hline Maltose & 12.23 & 15.42 \\
\hline Xylose & 10.05 & 12.31 \\
\hline Glucose & 9.01 & 10.26 \\
\hline
\end{tabular}

Effect of organic and inorganic nitrogen sources on xylanase production

The addition of organic and inorganic nitrogen sources on enzyme production was also studied. The nitrogen in the basal medium was replaced by various nitrogen sources with equimolar amounts. Concerning the inorganic nitrogen sources used as shown in Table 3, a slight increase in enzyme activity was observed with KNO3 in both Streptomyces species. In case of organic nitrogen sources, a maximum increase was observed with yeast extract rather than with peptone and casein (Table 3). In addition, yeast extract showed a maximum production comparable with different inorganic nitrogen sources. Thus, it could be concluded that yeast extract is beneficial for enzyme production, which is in accordance with the results of Balakrishnan et al. [2].

\section{Effect of growth period on xylanase production}

The results presented in Figs. (1 and 2) showed that xylanase was maximally produced at the 5th day of fermentation in both Streptomyces species. Xylanase production followed the growth curve of the strains. Maximum enzyme activity was observed at the end of the logarithmic phase and start of the stationary phase followed by decrease in activity with lag phase. 
Table 3. Effect of different nitrogen sources on xylanase production from Streptomyces species after 5 days in case of treated sample

\begin{tabular}{|l|c|c|}
\hline \multirow{2}{*}{ Nitrogen sources } & \multicolumn{2}{|c|}{ Maximum enzyme activity u/ml } \\
\cline { 2 - 3 } & Streptomyces albus & Streptomyces chromofuscus \\
\hline Inorganic nitrogen source & & \\
$\mathrm{KNO}_{3}$ & 78.78 & 89.27 \\
\hline $\mathrm{NaNO}_{3}$ & 74.49 & 84.26 \\
\hline $\mathrm{NH}_{4} \mathrm{NO}_{3}$ & 69.50 & 80.45 \\
\hline$\left(\mathrm{NH}_{4}\right)_{2} \mathrm{SO}_{4}$ & 76.56 & 87.31 \\
\hline $\mathrm{NH}_{4} \mathrm{H}_{2} \mathrm{PO}_{4}$ & 76.61 & 86.52 \\
\hline $\begin{array}{l}\text { Organic nitrogen source } \\
\text { Peptone }\end{array}$ & 63.31 & 74.14 \\
\hline Casein & 40.02 & 51.23 \\
\hline Yeast extract & 79.21 & 90.01 \\
\hline
\end{tabular}

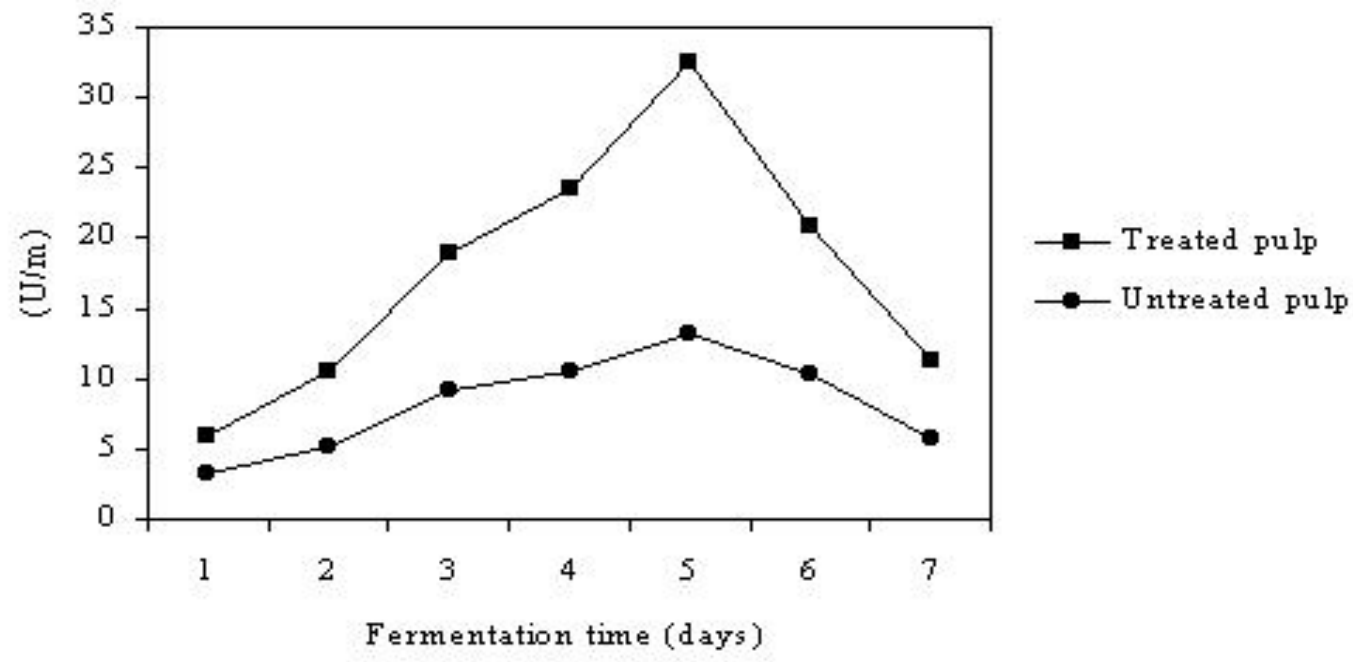

Figure 1. The effect of fermentation time (days) on xylanase production by Streptomyces albus

Hydrolysis of pulp

It is clear from Table 4 that hydrolysis of rice straw soft wood pulp with xylanase liberated reducing sugar from Streptomyces chromofuscus was more effective than from Streptomyces albus. The level of reducing sugars greatly increased with Streptomyces albus from 132 to $140 \mathrm{mg} / \mathrm{ml}$ and from 149 to $170 \mathrm{mg} / \mathrm{ml}$ with Streptomyces chromofuscus. Moreover, pulp treated with $\mathrm{TiO} 2$ enhanced hydrolysis, as a result increasing reducing sugar liberation and brightness, which is in accordance with the results of Nagieb et al. [16]. This means that xylanase treatment improved bleachability and did not affect the quality of the pulp. Such results are better than those of previously reported enzymes by some workers [7 and 27].

This implies that the coloured substance (s) in the crude pulp is probably bound to cellulose by xylan rather than by mannan. The degree of brightness in the case of Streptomyces albus increased from 45.1 to 47.2 (untreated) and to $49.1 \%$ (treated). A remarkable increase in brightness is observed in case of Streptomyces chromofuscus from 45.1 to 50.2 (untreated) and to $54.2 \%$ (treated). The Kappa no. in treated pulp 
decreased 4 points in the case of Streptomyces albus and dropped 7 points in the case of Streptomyces chromofuscus.

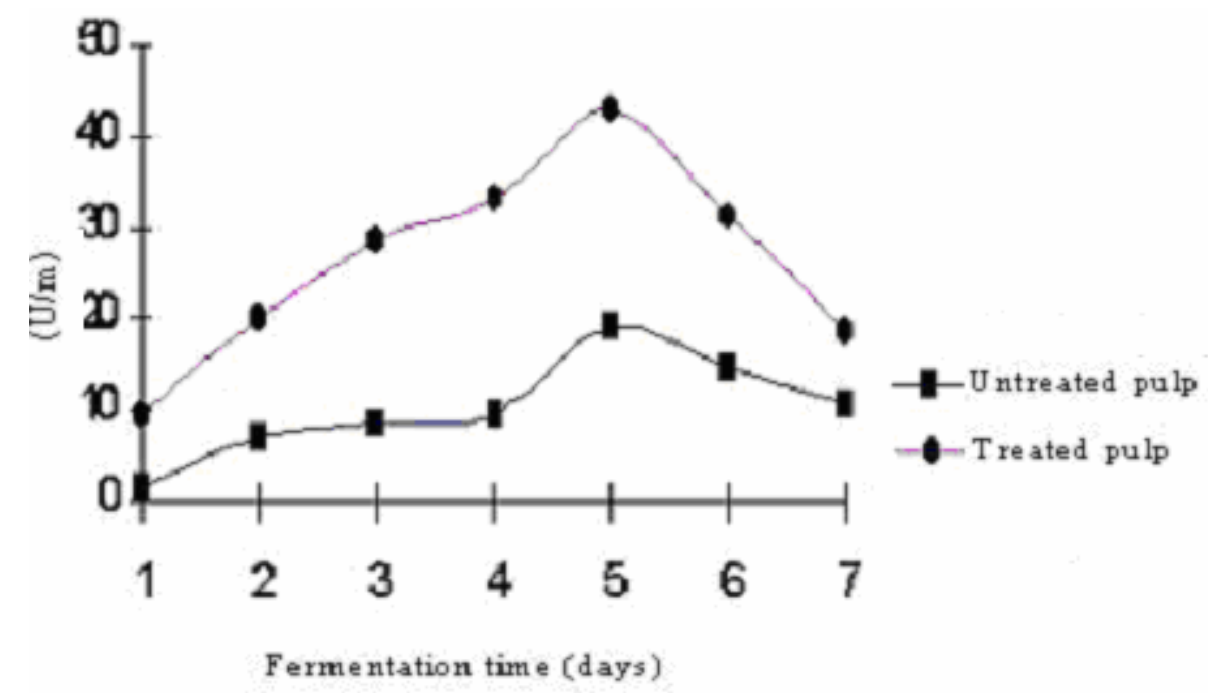

Figure 2. The effect of fermentation time (days) on xylanase production by Streptomyces chromofuscus

Table 4. Hydrolysis of soft wood rice straw pulp treated and untreated by Streptomyces species

\begin{tabular}{|l|l|c|c|c|c|}
\hline \multirow{2}{*}{$\begin{array}{c}\text { Strain } \\
\text { Streptomyces } \\
\text { albus }\end{array}$} & Samples & $\begin{array}{c}\text { Degree of } \\
\text { polymerization }\end{array}$ & $\begin{array}{c}\text { Kappa } \\
\text { No. }\end{array}$ & $\begin{array}{c}\text { Degree of } \\
\text { brightness }\end{array}$ & $\begin{array}{c}\text { Reduced } \\
\text { sugar mg/ml }\end{array}$ \\
\cline { 2 - 6 } & Blank & 960 & 17.2 & 45.1 & - \\
\cline { 2 - 6 } $\begin{array}{l}\text { Streptomyces } \\
\text { chromofuscus }\end{array}$ & Ureated & 970 & 15.2 & 47.2 & 132 \\
\cline { 2 - 6 } & Treated & 990 & 13.2 & 49.1 & 140 \\
\hline
\end{tabular}

The prepared enzyme had no cellulase activity and showed a noticeable increase in the degree of polymerization (DP). This may be due to the selective degradation of low molecular mass fractions of xylan [4]. The DP increases from 960 to 970 to 990 and from 960 to 995 to 1110 in the untreated and treated samples of Streptomyces albus and Streptomyces chromofuscus respectively (Table 4).

Reducing sugars were released in the treated samples, especially Streptomyces chromofuscus (up to $170 \mathrm{mg} / \mathrm{ml}$ ).

\section{Examination with the scanning electron microscope (SEM)}

In order to understand the effect of xylanase treatment on enhanced bleachability, the fiber surface morphology of the treated and untreated pulps without and with both Streptomyces species were studied by SEM. Significant changes on the fiber surface of the xylanase treated pulp were indicated by SEM as a result of xylan hydrolysis, while no surface effect was observed in untreated pulps (Fig. 4 and 5). Comparing hard sheets made from untreated and treated pulp, the SEM of the later shows that the white colour of $\mathrm{TiO} 2$ has permeated into fibers of pulp, and has unified the bands strongly together (Fig. $3 \mathrm{a}$ and b). In addition, the hard sheets made from pulp treated and untreated with 
Streptomyces albus reveals that the fibers treated with $\mathrm{TiO} 2$ exhibit a cleaner surface, apparent highly flexibility and conformability and a fiber with a vemar kable peeling effect rather than the control. Morphological changes such as holes, cracks, flakes, filaments and peeling are caused by enzyme treatment. These cracks and holes allow the diffusion of the larger lining macromolecules as reported by Wang et al. [28].

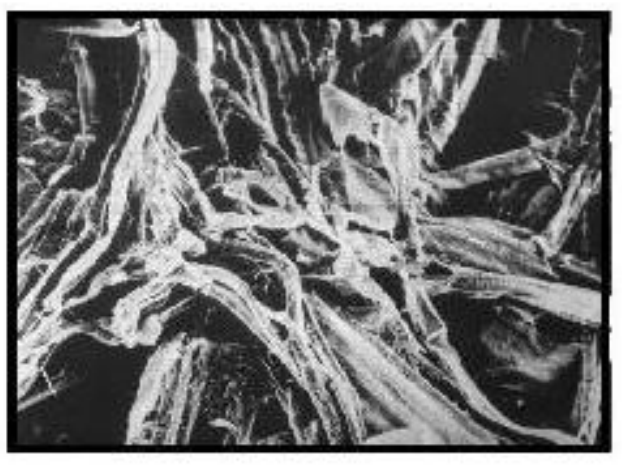

a

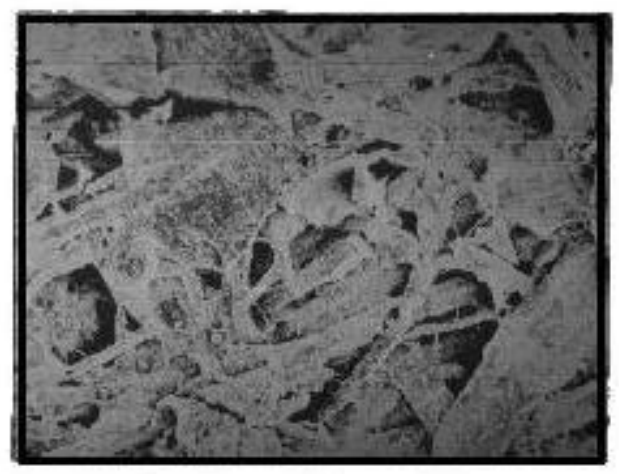

b

Figure 3. Photograph of SEM of hard sheets for untreated (a) and treated (b) pulp

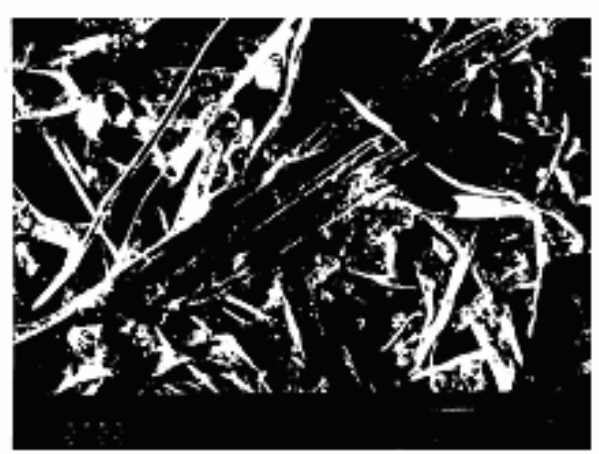

a

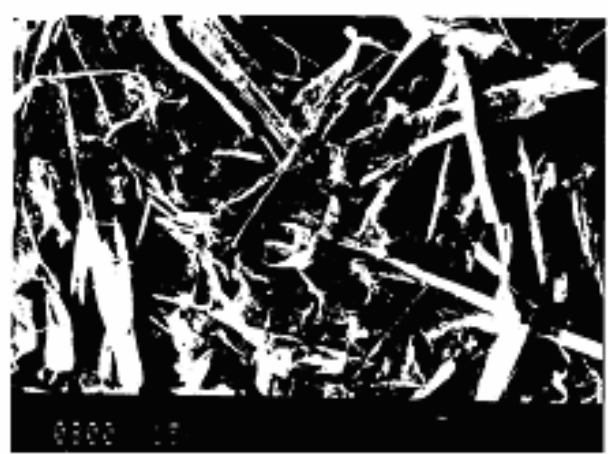

b

Figure 4. Photograph of SEM of hard sheets for untreated (a) and treated (b) pulp after treatments with xylanase producted by Streptomyces albus

Xylanase treatment improves accessibility of bleaching chemicals to the pulp and decreasing diffusion resistance to outward movement of the degraded lignin fragments from cell wall. SEM of hard sheets treatment with Streptomyces chromofuscus show cell wall swelling softening and collapse of the cell structure (Figs. 5. $a$ and b). Sachs et al. [21] came to the same observation. It is clear that hard sheet treated Streptomyces chromofuscus showing better apparent compressibility and bending as compared to treated by Streptomyces albus. This characteristic meets one of the required properties of the source of xylanase for the bleaching processes. 


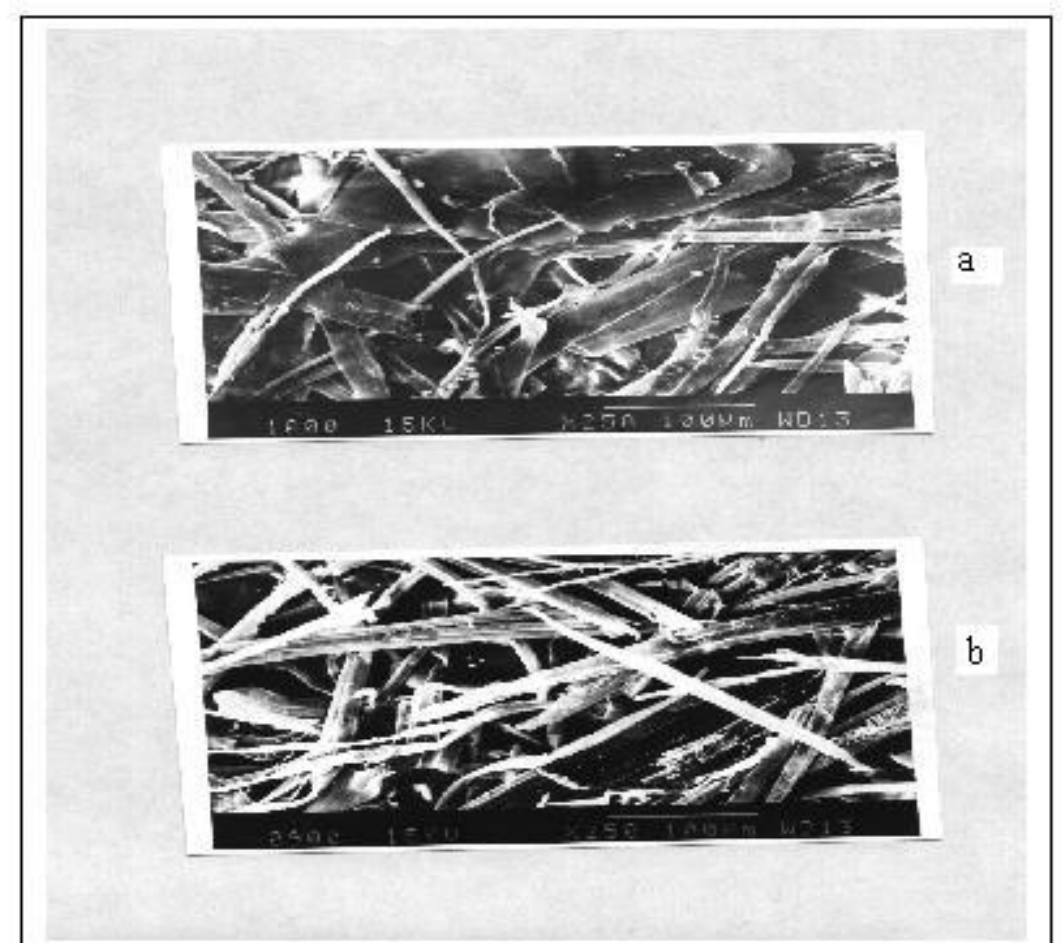

Figure 5. Photograph of SEM of hard sheets for untreated (a) and treated (b) pulp after treatments with xylanase produced by Streptomyces chromofuscus

In conclusion, the present study focuses on the production of cellulase free xylanase from Streptomyces species. However, not only the production level of xylanase, but also the ability to hyper produce enzyme on low cost agricultural residues such as rice straw. Xylanase produced by Streptomyces chromofuscus seems to be more efficient as compared with that of Streptomyces albus xylanase. So, the use of xylanase enzyme as an effective bio-reagents to achieve biobleaching in place of toxic chlorine compounds conventionally used today, is should be encouraged.

\section{REFERENCES}

[1] Antonopoulos, V. T., Hernandez, M., Arias, M. E., Mavrakos, E. and Ball, A. S. (2001): The use of extracellular enzymes from Streptomyces albus for the bleaching of eucalyptus Kraft pulp. - Applied Microbiology and Biotechnology 57: 92-97.

[2] Balakrishnan, H., Dutta-Choudhury, M., Srinivasan, M. C. and Rele, M. V. (1992): Cellulase-free xylanase production from an alkalophilic Bacillus species. - World Journal of Microbiology and Biotechnology 8: 627-631.

[3] Casey, J. P. (1981): Paper testing and converting. - In: pulp and Paper, vol.3, $3^{\text {rd }}$ ed., Interscience Publisher, New York 1714-1965.

[4] Christov, L. P. and Prior, B. A. (1993): Xylan removal from dissolving pulp using enzymes of Aureobasidium pullulans. - Biotechnological Letters 15: 1269-1274.

[5] Detroy, R. W. (1981): Bioconversion of agricultural biomass to organic chemicals. -In: I. S. Goldstein (Ed.), Organic chemicals from biomass. CRC Press, Inc., Boca Raton, Fla.: 19-43. 
[6] Grabski, A. C. and Jeffries, T. W. (1991): Production, purification characterisation of B- (1-4) endoxylanase of Streptomyces roseiscleroticus. - Applied Environmental Microbiology 57: 987-992.

[7] Gubitz, G. M., Schnitzhofer, H., Balakrishnan, H. and Steiner, W. (1996): Two mannanases from Sclerotium rolfsii in total chlorine free bleaching of soft wood Kraft pulp. - Journal of Biotechnology 50: 181-188.

[8] He, L., Bickerstaff, G. F., Paterson, A. and Buswell, J. A. (1993): Purification and partial characterisation of two xylanases that differ in hydrolysis of soluble and insoluble xylan fractions. - Enzyme Microbiology and Technology 15: 13-18.

[9] Holt, J. G., Sharpe, M. E. and Williams, S. T. (1989): Bergey's Manual of Systematic Bacteriology. Vol. 4. Williams and Wilkins. Baltimore, London.

[10] Kantalinen, A., Ratto, M., Sundqvist, J., Ranua, M., Viikari, L. and Linko, M. (1988): Hemicellulases and their potential role in bleaching. - In: 1988 International Pulp Bleaching Conference, Tappi Proceeding, Atlanta :1-9.

[11] Kantelinen, A., Sundqvist, J., Linko, M. and Viikari, L. (1991): The role of reprecipitated xylan in the enzymatic bleaching of Kraft pulp. - In: Proceeding of the $6^{\text {th }}$ International Symposium of Wood and Pulping Chemistry 1: 493-500.

[12] Keskar, S. S., Srinivasan, M. C. and Deshpande, V. V. (1989): Chemical modification of xylanase from a thermotolerant Streptomyces. - Biochemical Journal 261: 49-55.

[13] Kruss, I. and Koljonen, M. (1991): Enzymatic bleaching of pulp. - International Patent Application, no. w091/02791: 1-24.

[14] Kruss, I., Laine, J. and Koljonen, M. (1991): Improvement of oxygen bleaching of pulp. - International Patent Application, no. w091/02840: 1-19.

[15] Ludwig, W. and Strunk, D. (1997): ARB-A software environment for sequence data. TU Munchen: 1-127.

[16] Nagieb, Z. A., Abdel Hakeem, N. A., Tawfik, N. L., Abd-El-Aal, M. S. and Sakr, N. S. (2004): Application of spectroscopic techniques and physical parameters for studying the effect of rutile on the properties of wood pulp. - Restautator (in press).

[17] Nelson, N. (1945): A photometric adaptation of the Somogyi method for the determination of glucose. - Journal of Biology and Chemistry 160: 375.

[18] Paice, M., Bernier, M. and Jurasek, L. (1988): Viscosity enhancing bleaching of hard wood Kraft pulp with xylanase from a cloned gene. - Biotechnology and Bioengineering 32: 235-239.

[19] Petterson, R. C. (1984): The chemical composition of wood. - In: The chemistry of Solid Wood. Wowell, R. M. (Ed.), Advanced in Chemistry Series, 207, American Chemical Society, Washington, D. C.: 57-126.

[20] Roberts, J. C., McCarthy, A. J., Flynn, N. J. and Broda, P. (1990): Modification of paper properties by the pretreatment of pulp with Sacchromonospora viridis xyalnase. Enzyme Microbiology and Technology 12: 210-213.

[21] Sachs, I. B., Leatham, G. F., Myers, I. and Wengrer, T. H. (1990): Distinguishing characteristics of biomechanical pulp. - Tappi Proceeding, Atlanta 73: 249-254.

[22] Szabo, I. M., Marton, M., Buti, I. and Fernandez, C. (1975): A diagnostic key for the identification of species of Streptomyces and Streptoverticillum included in the International Streptomyces Project. - A Biological Academy of Science, Hungaria 21: $387-418$.

[23] Techapun, C., Chareonrat, T., Watanabe, M., Poosaran, N. and Sasaki, K. (2002): Thermostable and alkaline-tolerant cellulase-free xylanases produced from thermotolerant Streptomyces sp. Ab106. - Journal of Bioscience and Bioengineering 93: 431-433.

[24] Techapun, C., Poosaran, N., Watanabe, M. and Sasaki, K., (2003): Thermpstable and alkaline-tolerant microbial cellulase-free xylanases produced from agricultural wastes and the properties required for use in pulp bleaching bioprocesses: a review. - Process Biochemistry 38: 1327-1340. 
[25] Viikari, L., Kantelinen, A., Ratto, M. and Sundqvist, J., (1990): Enzymes for pulp and paper processing. - In: American Chemical Society Symposium Series, vol. 460, eds. Leathman, G. F. and Himmel, E. M., Washington DC: American Chemical Society: 1221.

[26] Viikari, L., Kantelinen, A., Ratto, M. and Sundqvist, J., (1991): Enzymes for pulp and paper processing. - In: Enzymes in Biomass conversion, Des Leatham, G. F. and Himmel, M. E.: 12-22.

[27] Viikari, L., Surnakki, A. and Buchert, J. (1996): Enzyme aided bleaching of Kraft pulp: Fundamental mechanisms and partial applications. - In: Jeffries, T. W. and Viikari, L. (Eds.), Enzymes for pulp and paper processing ASM, Washington, USA: 1524.

[28] Wang, L., Jiang, L. K. and Argyropoulos, D. S. (1997): Isolation and characterisation of lignin extracted from softwood Kraft pulp after the xylanase treatment. - Journal of Pulp Paper Science 23: 47-51.

[29] Wikerham. L. J. and Kurtzman, C. P. (1975): Synergistic colour variants of Aureobasidium pullulans. - Mycologia 67: 342-361.

[30] Williams, S. T., Goodfellow, N., Alderson, G., Wellington, E. M. H., Sneath, P. H. A. and Sackin, M. J. (1983): Numerical classification of Streptomyces and related genera. Journal of Genetic Microbiology 129: 1743-1813. 